\title{
Severe Cardiac and Renal Findings in an Adolescent Girl: Trandolapril/Verapamil Hydrochloride Overdose
}

Olgu Sunumu Case Report

Alındığı tarih: 20.06 .2019 Kabul tarihi: 30.08 .2019 Online Yayın tarihi: 31.12.2019

Demet Alaygut Tepecik Eğitim ve Araştırma Hastanesi Çocuk Nefroloji Kliniği, İmir - Türkiye alaygutdemet@gmail.com ORCID: 0000-0002-2164-4652

D. Orbatu 0000-0002-5716-2938 Tepecik Eğitim ve Araştırma Hastanesi Çocuk Sağlığı ve Hastalıkları, izmir, Türkiye

M.B. Oflaz 0000-0003-1515-4654 Cumhuriyet üniversitesi Tıp Fakültesi Çocuk Kardiyoloji Bölümü, Izmir, Türkiye

Cite as: Alaygut D, Orbatu D, Oflaz MB. Severe cardiac and renal findings in adolescen girls: Trandolapril/verapamil hydrochlorid overdose. Tepecik Eğit. ve Araşt. Hast. Dergisi. 2019;29(3):302-6.

\section{Bir Adolesan Kızda Trandolapril/Verapamil Hidroklorür Kombinasyon Toksisitesi Ile Ciddi Kardiyak ve Renal Bulgular}

\author{
Demet Alaygut $\odot$, Dilek Orbatu $\odot$, Mehmet Burhan Oflaz $\odot$
}

\begin{abstract}
Trandolapril/verapamil hydrochloride combination is an antihypertensive drug. A 15-year-old female patient was brought to our hospital with the findings of fatigue and somnolence. It was learnt that 12 hours before her admittance, she had taken tablets each containing $180 \mathrm{mg}$ verapamil and $2 \mathrm{ml}$ trandolapril. Temporary pacemaker was implanted to the patient for monitorization who had clinical picture of bradycardia, hypotension and acute renal failure and appropriate fluid treatment was administered. Pacemaker was removed after 12 hours because normal heart rhythm was restored. Acute renal failure was resolved with fluid replacement. This case was reported in order to present findings of cardiac and renal toxicity which may develop due to the use of fixed-dose combination drugs such as trandolapril/verapamil hydrochloride that are rarely prescribed in childhood and adolescent age group.
\end{abstract}

Keywords: Trandolapril, overdose, calcium channel blocker, angiotensin-converting enzyme inhibitor, adolescent, verapamil

Öz

Trandolapril/Verapamil Hidroklorid kombinasyonu bir antihipertansif ilaçtır. 15 yaşında kı hasta hastanemize halsizlik ve somnolans bulguları ile getirildi. Bassvurusundan 12 saat önce her bir tabletinde $180 \mathrm{mg}$ verapamil ve 2 mg trandolapril bulunan tabletlerden içtiği öğrenildi. Bradikardi, hipotansiyon ve akut böbrek hasarı tablosunda olan hastaya izlem amaçı geçici pacemaker takılarak uygun sıvı replasmanı sağlandı. Normal kalp ritminin sağlanmasından 12 saat sonra pacemaker çıkarıldı. Akut böbrek hasarı sıvı tedavisi ile düzeldi.Bu vaka çocukluk ve adolesan çağda Trandalopril/Verapamil gibi sabit doz da ilaç kombinasyonları içeren ve çocukluk çağında kullanımı nadir olan ilaçların toksisitesi ile ilgili gelişebilecek kardiyak ve renal toksisite bulgularını sunmak için yazılmıştır.

Anahtar kelimeler: Trandolapril, yüksek doz, kalsiyum kanal blokeri, anjiotensin konveting enzim, adolesan, verapamil

\section{INTRODUCTION}

Fixed-dose combination treatments in hypertension therapy are very frequently used. These drug combinations enable use of a single drug and single dose per day ${ }^{(1)}$. Tarka $R$ is a combination drug consisting of verapamil hydrochloride and trandolapril and it as $180-240 \mathrm{mg}$ verapamil and $1-4 \mathrm{mg}$ has various dosage combinations such trandolapril (1). INVEST (International Verapamil-trandolapril Study) study has shown that verapamil and trandolapril combination is useful on 22576 individuals having hypertensive and coronary artery disease in terms of both mortality and morbidity which has increased the chance of prescribing the drug especially for adults (2). Tarka may cause some adverse effects such as overdose lethargy, fatigue,
(C) Telif hakkı T.C. Sağılık Bakanlığı İzmir Tepecik Eğit. ve Araşt. Hastanesi. Logos Tıp Yayıncııık tarafindan yayınlanmaktadır. Bu dergide yayınlanan bütün makaleler Creative Commons Atff-GayriTicari 4.0 Uluslararası Lisansı ile lisanslanmıștır.

(c) Copyright Association of Publication of the T.C. Ministry of Health izmir Tepecik Education and Research Hospital.

(C) Copyright Association of Publication of the T.C. Min

This journal published by Logos Medical Publishing.

Licenced by Creative Commons Attribution-NonCommercial 4.0 International (CC BY-NC 4.0) 
sensory loss, bradycardia, hypotension, hyperglycemia, metabolic acidosis and shock ${ }^{(3)}$. Toxic dose of Tarka is not definitely known in the literature. However in some case reports; it is notified that lethal dose may occur with intake of 4-7 tablets, thus this may correspond to $720-1680 \mathrm{mg}$ verapamil and 8-14 mg trandolapril intake ${ }^{(3)}$. This paper represents a 15-year-old female patient who applied with complaints of fatigue and somnolence 12 hours after drug intake.

\section{CASE REPORT}

A 15-year-old female patient was admitted to our hospital due to somnolence and fatigue 12 hours after suicidal ingestion of six tablets of Tarka ${ }^{\circledR}$, each tablet of which contained $180 \mathrm{mg}$ verapamil and 2 $\mathrm{mg}$ trandolapril.

Activated charcoal was given to the patient who was referred from another hospital. Hypocalcemia (5,8 $\mathrm{mg} / \mathrm{dl}$ ) was also detected and she was given calcium gluconate intravenously. On physical examination, her body weight and height were $46 \mathrm{~kg}$ (10-25 percentile) and $163 \mathrm{~cm}$ (50 percentile) respectively. She was hypotensive $(80 / 50 \mathrm{mmHg}$ ) bradycardic (68/ $\mathrm{min}$ ) and had tachycardia (28/min). Otherwise her physical examination findings were within normal limits except for somnolence. During laboratory analyses, her complete blood count and liver function tests were normal except for leucocytosis and mild elevation of C-reactive protein. She had acute renal failure, hypocalcemia and hypopotassemia with normal arterial blood gas analysis results, prothrombin time, and activated partial thromboplastin time values. (Hemoglobin $12,7 \mathrm{~g} / \mathrm{dl}$, white blood cell 22.000/ $\mathrm{mm}^{3}$, C-reactive protein $18 \mathrm{mg} / \mathrm{dl}$, BUN $38 \mathrm{mg} / \mathrm{dl}$, creatinine $2.28 \mathrm{mg} / \mathrm{dl}$, AST $23 \mathrm{IU} / \mathrm{L}$, ALT $32 \mathrm{U} / \mathrm{L}$, LDH $176 \mathrm{U} / \mathrm{L}$, albumin $4.0 \mathrm{mg} / \mathrm{dl}$, phosphorus $4.38 \mathrm{mg} / \mathrm{dl}$, calcium $7.8 \mathrm{mg} / \mathrm{dl}$, sodium 138 $\mathrm{mmol} / \mathrm{l}$, potassium $3.3 \mathrm{mmol} / \mathrm{l}, \mathrm{pH}: 7.45 \mathrm{PCO}_{2}: 22$ $\left.\mathrm{mmHg}, \mathrm{HCO}_{3} 20 \mathrm{mmol} / \mathrm{l}\right)$. Hydration was provided with $\mathrm{NaCl} \% 0.9$ and an echocardiography was perfor- med (Figure 1). Temporary transvenous pacemaker was implanted because of bradycardia and hypotension and after the pacemaker placement, the vital findings began to return within normal limits (pulse rate: $80 / \mathrm{min}$, respiratory rate: $18 / \mathrm{min}$, arterial pres-

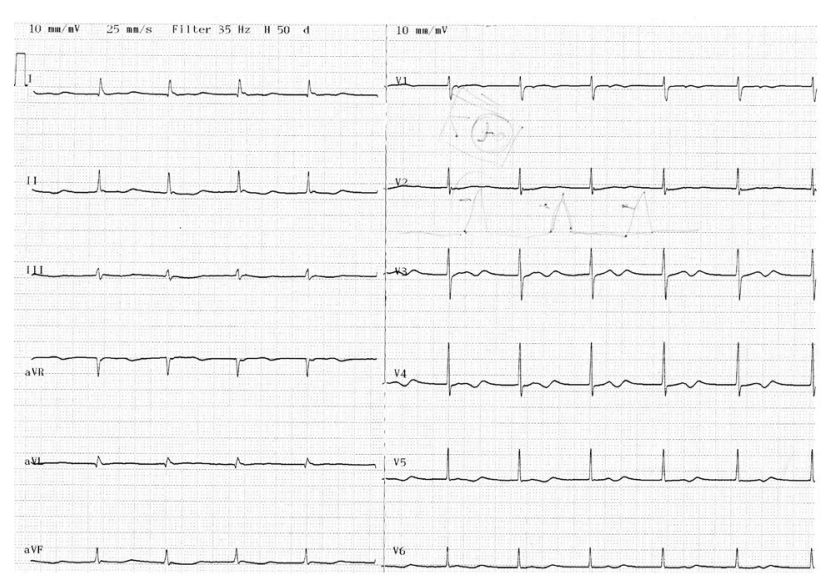

Figure 1. Bradycardia due to depression of the sinoatrial node, apperent $U$ waves in lead V3-5, early repolarization in V2 and long QT intervals (QTc $\sim 610 \mathrm{msec}$ ) of our patient before pacemaker insertion.

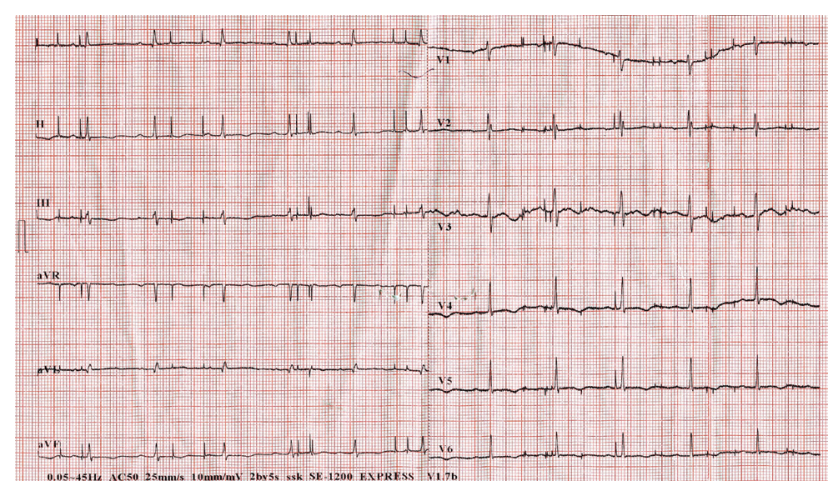

Figure 2. 1. degree AV block rhythm competing with pacemakers and long QT intervals (QTc: $480 \mathrm{msec}$ ).

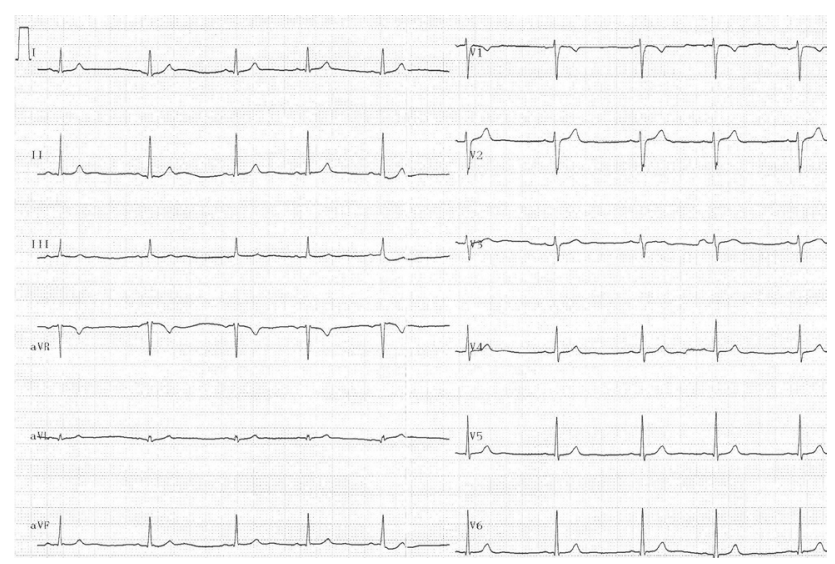

Figure 3. Normal sinus rhythm after pulling out of pacemaker. 
sure 100/80 mmHg) (Figure 2). Twelve hours after pacemaker implantation, the pacemaker was removed because normal heart rhythm was restored. Figure 3 illustrates ECG after removal of the pacemaker. Renal function started to recover after 24 hours. She was discharged with complete remission on day 3 of her hospitalization.

\section{DISCUSSION}

Tarka $^{\circledR}$ is an antihypertensive drug that is approved by US Food and Drug Administration and contains combination of verapamil SR and trandolapril (4). Verapamil is a calcium channel blocker (CCB). It is used in the treatment of hypertension, cardiac arrhythmias and angina. Sustained-release form of verapamil is also marketed (verapamil (SR) and one dose per day is sufficient due to its sustained release (5). Its significant part passes through the portal system and gets metabolized and it is converted to norverapamil that is its primary bioactive metabolite. Norverapamil has approximately $20 \%$ activity of verapamil ${ }^{(5)}$. In healthy individuals, peak verapamil and norverapamil concentrations are reached within 4-15 hours and 5-15 hours respectively. Besides, these periods may be prolonged with sustained release tablets ${ }^{(5)}$. A significant part, and metabolites of verapamil (70\%) are excreted through kidneys. Due to the wide usage area of verapamil and verapamil $S R$, numerous intoxication cases are reported in the literature ${ }^{(4)}$. Trandolapril is an angiotensin-converting enzyme inhibitor (ACE-I) and it reduces the angiotensin II level which is a potent vasoconstructor and decreases systemic blood pressure ${ }^{(6)}$. Furthermore, it can provide benefit for the type 2 diabetes mellitus patients whose renal functions deteriorated. Indeed, trandolapril and some other ACE inhibitors keep the blood pressure under control ${ }^{(6)}$. In human body, trandolapril is deesterified and converted into trandolaprilate which is 8-times more potent bioactive metabolite. Trandolaprilate reaches to the peak plasma concentration within 2-12 hours independent from simultaneous food intake. Urinary, and fecal
Clearance rates of trandolapril and its metabolites are $33 \%$ and $66 \%$ respectively ${ }^{(3)}$.

In trandolapril toxicity; patients are typically presented with hypotension and relative bradycardia. Noncardiac symptoms consist of lethargy, fatigue and changes in consciousness ${ }^{(5)}$. Severe angioedema and hypotension are the most serious adverse effects that distinguish trandolapril from the other ACE inhibitors. All of the reported trandolapril toxicities are associated with Tarka preparation. In CCB poisonings clinical manifestations of bradycardia, hypotension, hyperglycemia, metabolic acidosis and shock can be seen. Also the stroke is also reported in verapamil toxicity ${ }^{(7,8)}$. Toxicity with standard verapamil formulas occur normally within 2-4 hours after drug intake. However in cases with sustained-release verapamil toxicity symptoms appear 12 hours after drug intake and they may persist for $48-72$ hours ${ }^{(9,10)}$. In verapamil toxicity myocardial toxicity or the development of heart failure related to complete heart block are responsible for mortalities ${ }^{(11)}$. The symptoms of this case started 12 hours after intake of 6 Tarka tablets, each tablet containing $180 \mathrm{mg}$ verapamil and $2 \mathrm{mg}$ trandolapril and the first adverse symptom was fatigue. The patient ingested totally $1080 \mathrm{mg}(23 \mathrm{mg} / \mathrm{kg})$ verapamil and $12 \mathrm{mg}$ trandolapril $(0.26 \mathrm{mg} / \mathrm{kg})$. It was thought that symptoms of fatigue were related to trandolapril toxicity. Additionally, bradycardia and hypotension during the admittance may be observed in both trandolapril and verapamil toxicities. Even though other adverse effects such as hyperglycemia, complete AV block, flushing have been reported in the literature as manifestations of verapamil toxicity, we did not observe these side effects and leukocytosis and hypocalcemia were detected at admission.

Minimal toxic dose of verapamil has not been established clearly. Both in fetal and non-fetal cases doses of $800 \mathrm{mg}$ and $24000 \mathrm{mg}$ values have been indicated $(11,12)$. The average non-toxic dose of verapamil is 320 $\mathrm{mg}$ and its average toxic dose is $3.2 \mathrm{~g}^{(13)}$. Additionally, 
use of fixed-dose combinations, especially Tarka should be limited in children. Intoxication case reported by Doğan $\mathrm{M}$ et al. on a 3.5-year-old child is an examplary case for the early childhood period. The patient was brought with somnolence 7 hours after drug intake and pacemaker had been implanted because of hypotension and bradycardia that developed during follow-up. Gokel et al. reported two adult cases with thrombotic microangiopathy which developed after taking $180 \mathrm{mg}$ verapamil and $2 \mathrm{mg}$ trandolapril and also acute renal failure with rhabdomyolysis had developed (14,15). Additionally, our case had acute renal failure; and any laboratory finding did not suggest the presence of rhabdomyolysis and thrombotic microangiopathy. Renal failure was treated with appropriate fluid replacement and alkalinization of urine.

Batalis et al. ${ }^{(16)}$ reported a case who was found in an unconscious state 12 hours after taking Tarka and died within a short period of time. Cohen et al. (11) reported a 60-year-old male patient admitted with complaint of dizziness after taking 5 tablets of Tarka and he had been found in a hypotensive and bradycardic state 8 hours later.

In Tarka poisonings; lethargy and fatigue may be the first symptoms which should be definitely considered by the clinicians. The patients should be hospitalized for at least 24-48 hours if their clinical state worsens.

As in all other intoxication cases; primarily airways, respiration and circulation should be assessed in Tarka poisonings and crystalloid fluids should be given in the presence of hypotension (3). Activated charcoal can be given orally within up to 1 hour after drug intake. However in cases of toxicity with sustained-release verapamil; use of active charcoal after 2 hours may decrease absorption of the drug (17). In our case, activated charcoal was given about 12 hours after drug ingestion. Activated charcoal was not given again because the patient was not expec- ted to gain benefit from its application.

Due to the highly protein-bound state of verapamil, hemofiltration and hemodialysis treatment do not provide any benefit in verapamil intoxication, trandolapril overdose may be used ${ }^{(18)}$. Calcium treatment can be used in verapamil intoxication in order to provide the blockage of calcium channels ${ }^{(19)}$. We gave $1 \mathrm{mg} / \mathrm{kg}$ 10\% calcium gluconate bolus treatment to our patient for a single day at 12-hour intervals.

Various sympathomimetic drugs (dopamine, dobutamine, norepinephrine etc) can be used against hypotensive effect in CCB overdose ${ }^{(3)}$. However in this patient, immediate pacemaker implantation was performed without the need of such sympathomimetics and then her clinical picture improved.

Consequently, we did not find any suicidal intoxication cases related to Tarka in the literature. In such patients; especially in the development of cardiac side effects, immediate pacemaker implantation and in case of acute renal failure appropriate fluid replacement are critically important.

Conflict of Interest: None.

Informed Consent: Taken from family.

Çıkar Çatışması: Yoktur.

Hasta Onamı: Aileden alınmıştır.

\section{REFERENCES}

1. Steven G. Chrysant using fixed-dose combination therapies to achieve blood pressure goals. Clin Drug Invest. 2008;28(11):713-34. [CrossRef]

2. Pepine CJ, Handberg EM, Cooper-DeHoff RM et al. A calcium, antagonist vs a non-calcium antagonist hypertension treatment strategy for patients with coronary artery disease: the international Verapamil-Trandolapril Study (INVEST). A randomized controlled trial. JAMA. 2003;290(21):2805-16. [CrossRef]

3. Doğan $M$, Basaranoglu $M$, Peker $E$, Akbayram S, Sahin $M$, Uner A, et al. Tarka overdose in a young child. Human and Experimental Toxicology 30(9):1392-1398. [CrossRef]

4. Nick I. Batalis, Russell A. Harley and cynthia a. Schandl vera- 
pamil toxicity an unusual case report and review of the literature. The American Journal of Forensic Medicine and Pathology. 2007;28:2. [CrossRef]

5. Tarka, Physicians' Desk Reference, $59^{\text {th }}$ ed. Montvale, NJ: Thomson PDR; 2005.

6. Ruggenenti $P$, Fassi $A$, llieva AP, et al. Preventing microalbuminuria in type 2 diabetes. N Engl J Med. 2004;351:1941-51. [CrossRef]

7. Samniah $\mathrm{N}$ and Schlaeffer F. Cerebral infarction associated with oral verapamil overdose. J Toxicol Clin Toxicol. 1988;26:365-9. [CrossRef]

8. Shah AR and Passalacqua BR. Case report: sustained release verapamil overdose causing stroke: an unusual complication. Am J Med Sci. 1992;304:357-9. [CrossRef]

9. Barrow PM, Houston PL and Wong DT. Overdose of sustainedrelease verapamil. Br J Anaesth. 1994;72:361-5. [CrossRef]

10. Rankin RJ and Edwards IR. Overdose of sustained release verapamil. N Z Med J. 1990;103:165.

11. Cohen V, Jellinek SP, Fancher L, Sangwan G, Wakslak M, Marquart E, et al. Tarka(R) (Trandolapril/Verapamil hydrochloride extended-release) overdose. J Emerg Med. 2011;3:291-5. [CrossRef]
12. Ashraf M, Chaudhary K, Nelson J, Thompson W. Massive overdose of sustained-release verapamil: a case report and review of literature. Am J Med Sci. 1995;310:258-63.

13. Ramoska EA, Spiller HA, Myers A. Calcium channel blocker toxicity. Ann Emerg Med. 1990;19:649-53. [CrossRef]

14. Gokel Y, Paydas S, and Duru M. High-dose verapamil trandolapril induced rhabdomyolysis and acute renal failure. Am J Emerg Med. 2000;18:738-9. [CrossRef]

15. Gokel Y, Paydas S, Acikalin A, Bozkurt A. High-doseverapamil and trandolapril-induced thrombotic microangiopathy. Haematologia (Budap). 2002;32:281-5. [CrossRef]

16. Batalis NI, Harley RA, Schandl CA. Verapamil toxicity: an unusual case report and review of the literature. Am J Forensic Med Pathol. 2007;28:137-40. [CrossRef]

17. Laine K, Kivisto" KT, Neuvonen PJ. Effect of delayed administration of activated charcoal on the absorption of conventional and slow-release verapamil. J Toxicol Clin Toxicol. 1997;35:263-8. [CrossRef]

18. Kenny J. Treating overdose with calcium channel blockers. BMJ. 1994;308:992-3. [CrossRef]

19. Proano L, Chiang WK, Wang RY. Calcium channel blocker overdose. Am J Emerg Med. 1995;13:444-50. [CrossRef] 